\title{
River Water Quality Based on Macrozoobentic Bioindicators in the Wonocolo Traditional Oil Mining Area
}

\author{
Laily Agustina Rahmawati1 ${ }^{1,4}$, Norma Afiati ${ }^{1,2}$, Thomas Triadi Putranto ${ }^{1,3}$
}

${ }^{1}$ Doctorate Program in Environmental Science, School of Postgraduate, Diponegoro University; e-mail: laily.tiyangalit@gmail.com

${ }^{2}$ Department of Aquatic Resources Management, Faculty of Fisheries and Marine Sciences, Diponegoro University ${ }^{3}$ Department of Geology Technique, Faculty of Engineering, Diponegoro University

4Department of Environmental Science, Faculty of Science and Engineering, Bojonegoro University

\begin{abstract}
Many studies declared traditional oil mining in Wonocolo caused pollution, including river pollution. During Covid-19 Pandemic, traditional oil mining in Wonocolo has been interrupted because world oil prices decreased. This made selling price of crude oil in Wonocolo declined. This made traditional oil mining decreased because oil wells were temporarily closed. The decrease in traditional oil mining might affect river water quality in Wonocolo. In a prior study, the researcher had investigated water quality of Bungsu and Kragsaan River in Wonocolo, based on physicochemical parameters. The river had improved quality during Covid-19 Pandemic, seen from the decrease in the content of several chemical pollutants. Through this study, the researcher examined macrozoobentos community structure as a bio indicator of water quality, like assessing water quality of Bungsu and Kragsaan River based on biological indicators. This study used observation method by determining sample points purposively. Sample of macrozoobentos was analyzed using biodiversity index of Shannon-Wiener, species evennes index, and dominance index. Results of study showed Bungsu River had low biodiversity ( $\mathrm{H}^{\prime}$ index $0.000-$ 1.040), distressed community at B-1 and B-3 but stable at B-2, like high dominance at B-1 and B-3 but low at B-2. Kragsaan River also had low biodiversity ( $\mathrm{H}^{\prime}$ index $\left.0.000-1.010\right)$, unstable community at $\mathrm{K}-1$ and $\mathrm{K}-3$ like distressed at $\mathrm{K}-2$, and low dominance at K-2 and K-3 but medium at K-1. Based on H' index, Bungsu River was in the heavily polluted category at B-1 and B-3 and the medium polluted category at B-2. Meanwhile, Kragsaan River was in the heavily polluted category at K-1 and K-2 and the medium polluted category at K-3. This means although decreased levels of chemical pollutants at the sampling locations meant an increase in quality of water body, river ecosystem had not been able to rejuvenate condition during Covid19 Pandemic.
\end{abstract}

Keywords: Shannon-Wiener, Bentos, Water pollution, Traditional oil mining, Covid-19

Citation: Rahmawati, L.A., Afiati, N., dan Putranto, T.T. (2021). River Water Quality Based on Macrozoobentic Bioindicators in the Wonocolo Traditional Oil Mining Area. Jurnal Ilmu Lingkungan, 19(1), 29-35, doi:10.14710/jil.19.1.29-35

\section{Introduction}

The traditional oil mining area in Wonocolo is an area that currently has the status as one of the leading geosites in the Bojonegoro National Geopark. This area has unique geology related to the existence of anticlinal oil traps, as well as cultural uniqueness related to traditional mining methods that have been practiced for more than 120 years. The existence of this traditionally managed oil mine is often considered a threat to environmental sustainability, including that in the rivers in Wonocolo.

The Covid-19 pandemic, which has occurred since March 2020 in Indonesia, has had an impact on traditional petroleum mining activities that have been taking place in Wonocolo. Rahmawati, et al. (2021) stated that, during the Covid-19 pandemic, traditional oil mining activities in Wonocolo experienced a decline. This was due to the decline in world oil prices, which resulted in the low selling price of crude oil in Wonocolo, and this caused the miners to be unable to cover production costs. As a result, many miners decided to stop operating by temporarily closing oil wells. If traditional oil mining activities experience a decline during the Covid-19 pandemic, it may affect the quality of river water in Wonocolo.

Many previous studies have stated that the existence of traditional oil mines in Wonocolo caused the quality of river water in Wonocolo to be polluted (Hedar, 2018; Marwoto, 2012; Sari \& Trihadiningrum, 2018; Yogafanny, et al., 2019), based on physicochemical parameters of river water, before the Covid pandemic -19 in progress. However, the result of a research on river water quality in Wonocolo, during the Covid-19 pandemic, showed a different result from those of previous studies; namely, there was an increase in river quality during the pandemic. This could be observed from the decrease in the values of several chemical parameters, namely, COD, ammonia, sulfide, oil and fat, and phenols in the Wonocolo River, when these were compared to the 
Rahmawati, L.A., Afiati, N., dan Putranto, T.T. (2021). River Water Quality Based on Macrozoobentic Bioindicators in the Wonocolo Traditional Oil Mining Area. Jurnal IImu Lingkungan, 19(1), 29-35, doi:10.14710/jil.19.1.29-35

conditions before the Covid-19 pandemic (Rahmawati \& Setyoningrum, 2020). The improvement of river water quality, based on physicochemical parameters in Wonocolo, would be examined by the researchers, based on biological parameters through calculating the Macrozoobentic diversity index, through this study. In addition, there has been no research on the quality of Wonocolo river water based on biological indicators, and thus this research offers a new value in this area.

The role of biological indicators is also very important in assessing the quality of the environment. For example, the aspect of biodiversity, apart from its ability to show the water quality, is also an aspect that constitutes the goal of geopark development. As stated in Presidential Regulation No.9 of 2019, the goal of Geopark Development is to realize the preservation of geological heritage (Geoheritage), biological diversity (Biodiversity), and cultural diversity (Culture Diversity). Therefore, this aspect of biodiversity in Wonocolo really needs to be studied, including one aspect of biodiversity in the Macrozoobentic group.

Macrozoobentos are benthic animals with a size of $>1.0 \mathrm{~cm}$, where part or all of their life cycle is at the bottom of the water, and they play an important role in the decomposition and mineralization of organic material in waters (Asra, 2009; Sinaga, 2009). Macrozoobentos live relatively quietly and stay long enough on the waterbed, so that they are exposed to continuous water flow from time to time (Asra, 2009; Siahaan, et al., 2012). Therefore, the presence of Macrozoobentos in waters can be used as a biological indicator of water quality, including river water quality (Nangin et al., 2015).

The assessment of water quality using Macrozoobentic bioindicators can be determined through the Shannon-Wiener biodiversity index. The Shannon-Wiener biodiversity index value divides water quality into four groups, namely, heavily polluted, moderately polluted, lightly polluted, and very lightly polluted (Sujati, et al., 2017). Many other studies in Indonesia have used this method to determine the level of pollution in waters (Asra, 2009; Dubey, 2017; Izmiarti \& Savitri, 2018; Jamaludin \& Sri, 2014; Nangin, et al., 2015; Rahayu, et al., 2015; Siahaan, et al., 2012; Sinaga, 2009; Sujati, et al., 2017). However, research that uses indicators of Macrozoobentos abundance to determine water quality in Wonocolo has never been carried out. Even data related to marine biodiversity in the Wonocolo river are not found, and thus there is no comparative data.

This study aimed to examine the structure of the Macrozoobentic community as a bioindicator of water quality, as well as to assess the water quality of the Bungsu and Kragsaan rivers in Wonocolo based on biological indicators during the Covid-19 pandemic using the Shannon-Wiener diversity index. Furthermore, the results will be compared to confirm the conclusions of the quality study water, based on physicochemical parameters that have been carried out by researchers in previous studies.

\section{Research Methods}

The research was conducted in August 2020, during the dry season, in two rivers in Wonocolo, namely, the Bungsu River and the Kragsaan River. The two rivers receive waste input from traditional oil mining activities in Wonocolo without previous processing of the wastewater.

The research used the observation method by determining the sample points purposively, namely, in the upstream (in the form of springs), in the middle (mining locations), and in the middle of the forest (before mixing with other rivers), in accordance with the research objectives. The three points were selected to compare the condition of biodiversity in the upstream river, which does not receive waste input, with the middle part, which receives a lot of waste input, and the river part in the middle of the forest, which is assumed to have gone through the purification process.

The river water in Wonocolo in the dry season is relatively shallow, thus the Macrozoobentic samples were collected using a $20 \mathrm{~cm}$ diameter plastic pipe, which was plugged into the riverbed substrate as deep as $10 \mathrm{~cm}$. The substrate was taken from the river on the right, left and center. The substrate obtained was then filtered using a $1 \mathrm{~mm}$ sieve. Furthermore, the identification of Macrozoobentos was carried out in the Environmental Science laboratory of Bojonegoro University. Macrozoobentos sample details were observed with the aid of a 1000x magnification microscope. Then an analysis of the Macrozoobentic community structure was carried out by calculating the Shannon-Wiener biodiversity index (Krebs, 2009; Asra, 2009; Jamaludin and Sri, 2014; Nangin, et al., 2015; Siahaan, et al., 2012; Sinaga, 2009; Sujati, et al. , 2017), the species evennes index (Izmiarti, et al. 2018; Krebs, 2009), and the dominance index (Krebs, 2009), with the use of the following formula:

a. Sahannon-Wiener Biodiversity Index

Note:

$$
H^{\prime}=\sum_{n=i}^{S} p i \ln p i
$$

$\mathrm{H}^{\prime} \quad$ = Diversity index (Shannon-Wiener)

$\mathrm{Pi} \quad=n i / \mathrm{N}$

$\mathrm{ni}=$ Number of individuals of type $\mathrm{i}$

$\mathrm{N}=$ The number of all individuals

b. Species Evennes Index

Note:

$\mathrm{E}=$ Species Evennes Index

$\mathrm{H}^{\prime} \quad$ = Diversity Index

$\mathrm{S} \quad=$ Number of Species

c. Simpson Dominance Index

$$
C=\sum\left[\frac{n i}{N}\right]^{2}
$$


Note:

$\mathrm{C}=$ Dominance Index

ni $\quad=$ Number of individuals of the 1st species

$\mathrm{N}=$ Number of individuals of total species

Table 1. Community Structure Value Criteria

\begin{tabular}{ccc}
\hline \hline Index & Range & Category \\
\hline Dominance (C) & $0.00<\mathrm{C}<0.50$ & Low \\
& $0.50<\mathrm{C}<0.75$ & Moderate \\
& $0.75<\mathrm{C}<1.00$ & High \\
Biodiversity (H') & $\mathrm{H}^{\prime} \leq 2$ & Low \\
& $2.0<\mathrm{H}^{\prime} \leq 3.0$ & Moderate \\
$\mathrm{H}^{\prime} \geq 3.0$ & High \\
Evennes (E) & $0.00<\mathrm{E} \leq 0.50$ & $\begin{array}{c}\text { The community is in } \\
\text { under- pressure } \\
\end{array}$ \\
& $0.50<\mathrm{E} \leq 0.75$ & $\begin{array}{c}\text { (depressed) condition } \\
\text { The community is in an } \\
\text { unstable condition } \\
\end{array}$ \\
& $0.75<\mathrm{E} \leq 1.00$ & $\begin{array}{c}\text { The community is in } \\
\text { stable condition }\end{array}$ \\
& &
\end{tabular}

The determination of river water quality was performed with the Macrozoobentic biodiversity index in the Bungsu River and the Kragsaan River, based on Lee, et al., 1978, in Sujati, et al., 2017, as presented in Table 2.
Table 2. Classification of pollution levels based on the Diversity Index

\begin{tabular}{lc}
\hline \hline \multicolumn{1}{c}{ Diversity Index } & Diversity Index Pollution Level \\
\hline Very lightly polluted & $>3.0$ \\
Lightly polluted & $2.0-3.0$ \\
Moderately polluted & $1.0-2.0$ \\
Heavily polluted & $<1.0$ \\
\hline Source: Lee, et al., 1978 in Sujati, et al., 2017 &
\end{tabular}

\section{Results and Discussion}

Based on the analysis of Macrozoobentic samples, it was found that some of the benthic filtered in the 1 $\mathrm{mm}$ filter was dominated by foraminifera fossil. The abundance of foraminifer's fossils in the sediments of the Wonocolo river came from the mud that was brought to the ground during the oil well drilling process. The sludge was usually dumped directly into the river by the miners. The foraminifera that were carried along with the mud then flowed with the river flow and some of them settled on the riverbed.

For Macrozoobentos, the number of individuals found in the substrate samples in both rivers was very small; namely, in the Bungsu River there were only 9 individuals, out of 3 species, and in the Kragsaan River only 45 individuals, from 8 species. The types of Macrozoobentos found in the two rivers came from 3 classes; namely, polychaeta, bivalve and gastropods (table 3).

Table 3. Number of Individuals and Macrozoobentic Diversity Index in Bungsu and Kragsaan Rivers, Wonocolo

\begin{tabular}{|c|c|c|c|c|c|c|c|c|c|}
\hline \multirow{4}{*}{ Class } & \multirow{4}{*}{ Taxa } & \multicolumn{8}{|c|}{ Sample } \\
\hline & & \multicolumn{4}{|c|}{ Bungsu River Station } & \multicolumn{4}{|c|}{ Kragsaan River Station } \\
\hline & & B-I & B-2 & $\mathrm{B}-3$ & Total & B-I & B-2 & B-3 St. & Total \\
\hline & & St. & St. & St. & & St. & St. & & \\
\hline Polychaeta & - & 1 & 2 & 4 & 7 & 1 & - & 21 & 22 \\
\hline Bivalvia & Pilsbryoconcha sp. (freshwater clam) & - & 1 & - & 1 & - & - & - & - \\
\hline \multirow{7}{*}{ Gastropoda } & limpet & - & 1 & - & 1 & 1 & - & - & 1 \\
\hline & Thiara scabra & - & - & - & - & - & - & 6 & 6 \\
\hline & Melanoides tuberculata & - & - & - & - & 10 & - & - & 10 \\
\hline & Tarebia granifera & - & - & - & - & - & - & 1 & 1 \\
\hline & Gyraulus convexiusculus & - & - & - & - & - & - & 1 & 1 \\
\hline & Melanoides sp. & - & - & - & - & - & - & 4 & 4 \\
\hline & Total & 1 & 4 & 4 & 9 & 12 & 0 & 33 & 45 \\
\hline
\end{tabular}

The polychaeta class was found in almost all observation sub-stations on the Wonocolo River. In tropical regions of the world, freshwater polychaeta are often abundant in highly polluted rivers and are quite tolerant of low dissolved oxygen conditions, and thus they are often used as bio-indicators for enrichment of anthropogenic nutrients in lotic waters (Benbow, 2009).

The existence of bivalves was only found in Bungsu River, at the observation sub-station B-2. The site received a lot of waste oil input from the traditional Wonocolo mine, with the riverbed at the location being very muddy. The type of bivalvia found was Pilsbryoconcha sp. (freshwater clam). The clam has the ability to survive in waters with low oxygen content, lives well on muddy substrates (Komarawidjaja, 2006) and has the ability to accumulate pollutants, and thus it is often used as a heavy metal bio-indicator (Purbonegoro, 2018; Radwan, et al., 2018).
The gastropod class was the largest Macrozoobentos found in the Kragsan River, especially at the K-1 and K-3 observation sub-stations, which had clearer water conditions compared to substation 2, with a total of 24 individuals. Gastropods dominated the Kragsaan River because this type can live well in various places and weather (Fadhilah, et al., 2013). The type of gastropod that dominated the Kragsaan River was Melanoides tuberculate, which is commonly found in almost all types of freshwater ecosystems and is an invasive species, because it has a high tolerance to various environmental changes (Purnama, et al., 2019).

\subsection{Macrozoobentic Community Structure}

a. Biodiversity Index

Based on the results of Macrozoobentic analysis of the Shannon-Wiener biodiversity index, it was found that the highest $\mathrm{H}$ 'value in the Bungsu River was at the B-2 observation sub-station, which was 1.04 , and thus it was included in the low diversity 
category. Likewise, at sub-stations B-1 and B-3, the value of $\mathrm{H}$ 'was 0.000 as listed in Table 4.

For the Kragsaan River, as shown in Table 4, the biodiversity index in the three monitoring stations also had an $\mathrm{H}^{\prime}$ value below 2 , and thus it means that biodiversity was in the low category. It is to be noted that rivers of good quality should have high biodiversity, which means that rivers are able to support the organisms that live in them (Siahaan, et al., 2012).

Table 4. Structure of the Macrozoobentic Community in the Bungsu and Kragsaan Rivers, Wonocolo

\begin{tabular}{|c|c|c|c|c|c|c|c|c|}
\hline \multirow{4}{*}{ Community Structure Variable } & \multicolumn{8}{|c|}{ Sample } \\
\hline & \multicolumn{4}{|c|}{ Bungsu River Station } & \multicolumn{4}{|c|}{ Kragsaan River Station } \\
\hline & B-I & B-2 & B-3 & Total & B-I & B-2 & B-3 & Total \\
\hline & St. & St. & St. & & St. & St. & St. & \\
\hline Total of taxa, species & 1.000 & 3.000 & 1.000 & 5.000 & 3.000 & 0.000 & 5.000 & 8.000 \\
\hline Abundance Total & 1.000 & 4.000 & 4.000 & 9.000 & 12.000 & 0.000 & 33.000 & 45.000 \\
\hline Diversity Index & 0.000 & 1.040 & 0.000 & - & 0.570 & 0.000 & 1.010 & - \\
\hline Maximum diversity & 0.000 & 1.099 & 0.000 & - & 1.099 & 0.000 & 1.609 & - \\
\hline Species evennes Index & 0.000 & 0.946 & 0.000 & - & 0.519 & 0.000 & 0.628 & - \\
\hline Dominance Index & 1.000 & 0.375 & 1.000 & - & 0.708 & 0.000 & 0.455 & - \\
\hline
\end{tabular}

The pattern of increasing biodiversity in the Bungsu River from the upstream (B-1), which comprises water sources, increased in the middle (B2 ) and decreased again in the forest area (B-3). The lack of biodiversity in B-1 might be due to the limited water sources in that location. The water source at sub-station B-1, at the time of sampling, moved with a very low flow, because it coincided with the dry season. This condition made the river body in substation B-1 very dry, and the substrate was very limited. In sub-station B-2, although a lot of oil well waste is disposed of at that location, the amount of water that filled the river body was much more abundant. Most of the water came from oil wells and came out with oil during the mining process.

Sub-station B-3 had different conditions from rivers in general, because it had water with high salinity even though the location was not near the sea. The high salinity in the Bungsu River was seen from several parameters, namely, conductivity, chloride and sodium content. The water conductivity value of the Bungsu River reached $14420 \mu \mathrm{S} / \mathrm{cm}$ (Rahmawati, et al., 2020), whereas for river water generally ranges from 200-1500 $\mu \mathrm{S}$ / cm (Mutmainah, et al., 2018). In addition, the chloride content in the Bungsu River was also very high, up to $3124 \mathrm{mg} / \mathrm{l}$ (Rahmawati, et al., 2020). This value was much higher than the standard value for water quality in accordance with the Regulation of the Minister of Health No. 416 / Menkes / Per. / IX / 1990, which is 600 mg / l (Sasongko, et al., 2014). Likewise, the sodium level in the Bungsu River was $3.17 \mathrm{mg} / \mathrm{l}$ (Rahmawati, et al., 2020); this value far exceeds the water quality standard based on Government Regulation Number 82 of 2001, which is $0.03 \mathrm{mg} / \mathrm{l}$.

Unlike the Bungsu River, the pattern of increasing the biodiversity index $\left(\mathrm{H}^{\prime}\right)$ in the Kragsan River from the upstream (K-1), which comprises water sources, was initially high, then decreased in the middle (K-2), and rose higher in forest areas (K-3). The $\mathrm{H}$ 'value in the upper reaches of the Keragsan River was higher when compared to the Bungsu River, because at substation K-1 the water source was bigger, and thus the puddle in that location was much larger in volume than that of sub-station B-1. A greater volume of stagnant water caused a higher likelihood of living water biota, including Macrozoobentos. The decline in biodiversity in the K-2 sub-station was because fact that the water was very cloudy in that location, with a very high TDS value, namely 17600-22200 mg / l, far exceeding the river water quality standard, which is $1000 \mathrm{mg} / \mathrm{l}$. In addition, the COD value at the K-2 substation was also quite high, up to $47.2 \mathrm{mg} / \mathrm{l}$, while the standard quality standard for COD was only around 25 mg / l (Rahmawati, et al. 2020). These conditions might be the cause of the very low biodiversity in the $\mathrm{K}-2$ sub-station. The highest $\mathrm{H}$ 'value was at $\mathrm{K}-3$ substation. This might be related to the availability of food originating from the leaves of plants in the forest that entered the water bodies of the Kragsaan River. In these locations, there were many rotting leaves, which made the waters rich in organic matter / nutrients. This condition was similar to that in the research of Pelealu, et al. (2018), which stated that the abundance and diversity of Macrozoobentos, apart from being influenced by physical factors (depth, current velocity, turbidity, temperature, etc.), was also greatly influenced by chemical factors, including organic / nutrient content, dissolved oxygen, etc. In addition, it was also determined by biological factors, especially the existence of producers, which constitute a source of food for Macrozoobentos.

\section{b. Species Evennes Index}

The species evennes index (E) is a value that shows the pattern of the distribution of the biota or individual composition of each species in a community. Greater E value indicates an abundance that is almost uniform and evenly distributed between species (Latuconsina, 2020).

The highest species evennes index (E) in the Bungsu River was at sub-station B-2, which is 0.946 . This value showed that the community in sub-station B-2 was in stable condition (Latuconsina, 2020). This was different from the condition of sub-stations B-1 and B-3 whose E value was 0.000 , which means that the community in that location was in under-pressure (depressed) condition. The low E value at sub-station 
B-1 was also caused by the fact that in that location the condition of standing water from the spring was very minimal (almost dry). The E value at sub-station B-3 was also low, possibly influenced by the high salinity at that location. The reason was that not all freshwater organisms could survive the conditions of river water with high salinity.

The species evennes index (E) on the Kragsaan River at K-1 sub-station was 0.519 and K-3 was 0.628, and this means that the communities in the two substations were in an unstable condition. For the K-2 sub-station, it had an E value of 0.000 , which means that the community in the sub-station was in underpressure (depressed) state (Latuconsina, 2020). The low $\mathrm{E}$ value at the $\mathrm{K}-2$ sub-station was due to the very high turbidity and COD at that location, thus making the water conditions not ideal for the growth of aquatic biota, including macrozoobentos.

The difference in the species evennes index value (E) between sub-stations and between rivers was caused by water physics factors, nutrient availability and differences in nutrient utilization by each individual (Sirait, et al., 2018). Therefore, turbidity, COD, nutrient content, and salinity greatly determine the value of species evennes in the Wonocolo river.

\section{c. Simpson Dominance Index}

The species dominance index shows whether there are dominant species in a community. The existence of a dominant species will affect the balance of the population in a community, for example, the emergence of competition in utilizing Natural Resources (SDA), so that environmental conditions become depressed (Sirait, et al., 2018).

The species dominance index in the Bungsu River at sub-stations B-1 and B-3 was very high, namely
1.000 (Table 4). The high dominance value was because in the two sub-stations only one species was found. At sub-station B-2, the dominance value was low because 3 species were found in one observation station.

In the Kragsaan River, the species dominance values were in the moderate to low range in the three observation sub-stations. Based on the species dominance value, the Kragsaan River, with lower average dominance values- starting from the K-1 to K3 sub-stations, would have a more balanced community than the Bungsu River. Apart from the low dominance value, the diversity of Macrozoobentic organisms in the Kragsaan River was also more diverse compared to that in the Bungsu River.

\subsection{Pollution Level of Bungsu River and Kragsaan River Based on Biodiversity Index}

Based on the Macrozoobentic biodiversity index value in the Bungsu River, the levels of pollution at sub-stations B-1 and B-3 were in the heavily polluted category (Table 5). Meanwhile, the level of pollution at sub-station B-2 was in the medium pollution category. Even though at sub-station B-1 the river had not received waste input from the oil well, the limited amount of water made it difficult for Macrozoobentos to live in that place. At sub-station B-2, the status of the Bungsu River had increased to be moderately polluted; although this point received waste input from oil wells, the turbidity and COD levels in this location were still relatively low. This might be influenced by the decline in oil mining activity during the Covid-19 pandemic (Rahmawati, 2021), which coincided with the time the research was taking place.

Table 5. Categories of Value of Macrozoobentic Community Structure and Pollution Level Based on the Macrozoobentic Biodiversity Index in the Bungsu and Kragsaan Rivers, Wonocolo

\begin{tabular}{|c|c|c|c|c|c|c|}
\hline \multirow{4}{*}{$\begin{array}{c}\text { Variables of } \\
\text { Community Structure } \\
\text { and Pollution Level }\end{array}$} & \multicolumn{6}{|c|}{ Sample } \\
\hline & \multicolumn{3}{|c|}{ Bungsu River Station } & \multicolumn{3}{|c|}{ Kragsaan River Station } \\
\hline & B-I & B-2 & B-3 & B-I & B-2 & B-3 \\
\hline & St. & St. & St. & St. & St. & St. \\
\hline Diversity Index & Low Diversity & Low Diversity & Low Diversity & Low Diversity & Low Diversity & Low Diversity \\
\hline $\begin{array}{l}\text { Species Evennes } \\
\text { Index }\end{array}$ & $\begin{array}{l}\text { Community in } \\
\text { under-pressure } \\
\text { condition }\end{array}$ & $\begin{array}{l}\text { Community } \\
\text { in stable } \\
\text { condition }\end{array}$ & $\begin{array}{l}\text { Community in } \\
\text { under-pressure } \\
\text { condition }\end{array}$ & $\begin{array}{l}\text { Community in } \\
\text { unstable } \\
\text { condition }\end{array}$ & $\begin{array}{l}\text { Community in } \\
\text { under-pressure } \\
\text { condition }\end{array}$ & $\begin{array}{l}\text { Community in } \\
\text { unstable } \\
\text { condition }\end{array}$ \\
\hline Dominance Index & High dominance & $\begin{array}{c}\text { Low } \\
\text { Dominance }\end{array}$ & High dominance & $\begin{array}{c}\text { Medium } \\
\text { Dominance }\end{array}$ & Low Dominance & Low Dominance \\
\hline $\begin{array}{l}\text { Pollution Level Based } \\
\text { on Diversity Index }\end{array}$ & Heavily polluted & $\begin{array}{l}\text { Moderately } \\
\text { polluted }\end{array}$ & Heavily polluted & Heavily polluted & Heavily polluted & $\begin{array}{l}\text { Moderately } \\
\text { polluted }\end{array}$ \\
\hline
\end{tabular}

In the Kragsaan River, the level of pollution based on the Macrozoobentic biodiversity index in the K-1 and $\mathrm{K}-2$ sub-stations were in the heavily polluted category, while that in the K-3 sub-stations was in the medium-polluted category. Like the Bungsu River, the upper reaches of the Kragsaan River (K-1) was also a spring with a limited amount of water, and thus it could not support the life of organisms optimally. The
K-2 sub-station was a location that received direct waste input from oil wells. Although mining activity decreased during the pandemic, the turbidity and COD values at this location were the highest compared to other locations. The physical condition of these waters might be the cause of the absence of Macrozoobentos in this sub-station. In the K-3 sub-station, the physicochemical conditions of the waters were relatively 
better than the other sub-stations. This caused the number and types of Macrozoobentos to be mostly found in the K-3 sub-station.

The pollution in the Bungsu and Kragsaan rivers occurred due to the influence of traditional petroleum mining activities that have been going on in the area for more than 120 years. Traditional oil mining activities in Wonocolo only use simple technology and do not have a sewage treatment plant. The water that comes out with the petroleum is manually separated in reservoirs. Furthermore, the remaining water is disposed of directly into the river, even though the water is often mixed with oil.

The low biodiversity in the two rivers in Wonocolo indicated that the river was unable to support the organisms that live in the river due to the condition of the river being polluted. When filtering the substrate samples for Macrozoobentos identification, the smell of sludge was very strong and visually it could be seen that oil stuck to the substrate when the water was separated. Oils and fats are types of solids that can emulsify, cannot evaporate and have a complex structure that is difficult to decipher (Hedar, 2018). The existence of oil and fat waste will form a brownish layer on the surface of the water so that it can block sunlight from entering the water (Asra, 2009; Setyaningrum, et al., 2020), so that it will inhibit the photosynthesis process of phytoplankton (Asra, 2009). In fact, the presence of phytoplankton in the waters is very important, because it plays a role as a producer that provides food for other aquatic organisms, including Macrozoobentos.

\subsection{Comparison of Pollution Levels of Bungsu and Kragsaan Rivers based on Macrozoobentic Biodiversity Index and Physico-Chemical Parameters}

In this series of studies, the researchers have also studied the water quality of the Bungsu and Kragsaan rivers based on physico-chemical parameters. The results showed that during the Covid-19 pandemic the water quality of the Bungsu and Kragsaan rivers improved during the pandemic, and this was marked by a decrease in the value of several chemical parameters, such as COD, ammonia, sulfides, oils and fats, and phenols, in the Wonocolo River, when compared to the conditions before the pandemic. Covid-19 (Hedar, 2018; Rahmawati \& Setyoningrum, 2020). However, when compared with the results of river water quality assessment based on biological parameters- namely, Macrozoobentic diversity, it turns out that the quality of the two rivers could be categorized as heavily polluted and moderately polluted. The decline in the value of several chemical parameters occurred due to the decline in traditional oil mining activities during the Covid-19 pandemic (March-August 2020). This condition could be interpreted that although the content of chemical pollutants had decreased during the pandemic, the river ecosystem had not been able to restore its condition to support the life of the organisms that lived in it within the 6-month period.

\section{Conclusion}

Based on the results of research on Macrozoobentos as bioindicators of water quality in the Wonocolo river, the following conclusion was declared. Based on the Macrozoobentic species evennes index, in the Bungsu River, the community was in under-pressure (depressed) condition, at substations B-1 and B-3, and in stable condition, at substation B-2. In the Kragsaan River, it was in unstable condition, at $\mathrm{K}-1$ and $\mathrm{K}-3$ sub-stations, and was in under-pressure condition, at K-2 sub-stations.

Based on the dominance index, the Bungsu River had high species dominance, at sub-station B-1 and B3 , and low dominance, at sub-station B-2. In the Kragsaan River, it had low dominance, at K-2 and K-3 sub-stations, and medium dominance, at K-1 substations. On the Macrozoobentic biodiversity index, both the Bungsu and Kragsaan rivers were in the low category.

Based on the biodiversity index, the pollution level of the Bungsu River was in the heavily polluted category, at sub-stations B-1 and B-3, and in the medium-polluted category, at sub-stations B-2. Meanwhile, at the Kragsaan River, the level of pollution was in the heavily polluted category, at K-1 and $\mathrm{K}-2$ sub-stations, and in the medium-polluted category, at K-3 sub-stations.

These results indicate different conditions when compared with the results of the assessment of water quality at the Bungsu and Kragsaan rivers based on physico-chemical parameters. Even though there was a decrease in the levels of chemical pollutants in the sampling locations-which means an increase in the quality of water bodies, it turned out that the river ecosystem had not been able to restore its condition during the Covid-19 pandemic period.

\section{Acknowledgment}

Deep gratitude is expressed to the Directorate of Research and Community Service, Deputy for Strengthening Research and Development, Ministry of Research and Technology / National Research and Innovation Agency, which provides funding through the Beginner Lecturer Research (PDP) grant scheme.

\section{REFERENCES}

Asra, R. 2009. Makrozoobentos Sebagai Indikator Biologi Dari Kualitas Air di Sungai Kumpeh Dan Danau ArangArang Kabupaten Muaro Jambi, Jambi. Jurnal Biospecies. Vol. 2 No. 1. Hal 23-25.

Benbow, M.E. 2009. Annelida, Oligochaeta and Polychaeta. Reference Module in Earth Systems and Environmental Sciences. Encyclopedia of Inland Waters. Pages 124-127.

Dubey, K. 2017. Socio Economic Impact Study of Mining and Mining Polices on the Livelihoods of Local Population in the Vindhyan Region of Uttar Pradesh. Centre for Social Forestry and Eco-Rehabilitation. Pages 1-152.

Fadhilah, N. Masrianih, Sutrisnawati. 2013. Keanekaragaman Gastropoda Air Tawar di Berbagai Macam Habitat di Kecamatan Tanambulava Kabupaten Sigi. e-Jipbiol Vol. 2. Hal. 13-19. 
Hedar, Y. 2018. Kualitas Air Sungai (Studi Kasus Penambangan Tradisional Minyak Bumi Di Desa Wonocolo Kecamatan Kedewan Kabupaten Bojonegoro). Tesis. Seolah Pascasarjana Universitas Diponegoro.

Izmiarti, dan Savitri, V. 2018. Komunitas Makrozoobentos sebagai Indikator Biologis Kualitas Air Sungai Masang Kecil yang Menerima Limbah Cair Industri Minyak Kelapa Sawit di Kinali Pasaman Barat Macrozoobentos Community as Biological Indicator of Water Quality Masang Kecil River Recei. Jurnal Biologi Universitas Andalas (J. Bio. UA.). Vol. 6 No. 1. Hal. 3644.

Jamaludin Afif, Sri Ngabekti, T. A. P. 2014. Keanekaragaman Makrozoobentos Sebagai Indikator Kualitas Perairan Di Ekosistem Mangrove Wilayah Tapak Kelurahan Tugurejo Kota Semarang. Journal of Life Science Unnes. Vol. 3 No. 1. Hal. 47-52.

Krebs, C.J. 2009. Ecology: The Experimental Analysis of Distribution and Abundance. Pearson Benjamin Cummings. San Francisco.

Marwoto. 2012. Analisis Masalah dan Strategi Pengelolaan Sumur Tua di Blok Cepu. Tesis. Sekolah Pascasarjana IPB.

Mutmainah, H., dan Adnan, I. 2018. Status Kualitas Perairan Kawasan Terpadu Pelabuhan Perikanan Samudera Bungus Menggunakan Metode Indeks Golongan Air. Jurnal Teknologi Lingkungan Vol. 19 No. 1. Hal. 107116.

Nangin, S. R., Langoya, M. L., dan Katilia, D. Y. 2015. Makrozoobentos Sebagai Indikator Biologis dalam. Jurnal Mipa Unsrat. Vol. 4 No. 2. Hal. 165-168.

Pelealu, G.V.E., Koneri, R., dan Butarbutar, R.R. 2018. Kelimpahan Dan Keanekaragaman Makrozoobentos Di Sungai Air Terjun Tunan, Talawaan, Minahasa Utara, Sulawesi Utara. Jurnal Ilmiah Sains. Vol. 18 No. 2. Hal. 97-102.

Peraturan Presiden Nomor 9 Tahun 2019 tentang Pengembangan Taman Bumi (Geopark).

Peraturan Pemerintah No. 82 Tahun 2001 tentang Pengelolaan Kualitas Air dan Pengendalian Pencemaran Air.

Purbonegoro, T. 2018. Potensi Bivalvia Sebagai Bioindikator Pencemaran Logam Di Wilayah Pesisir. Oseana, Vol. XLIII No. 3. Hal. 61 - 71

Purnama, M.F., Admaja, A.K., dan Haslianti. 2019. Bivalvia dan Gastropoda Perairan Tawar di Sulawesi Tenggara. Jurnal Penelitian Perikanan Indonesia. Vol. 25 No. 3. Hal. 191-202.

Radwan, E.H., Mawgood, A.A., Ghonim, A.Z., and El Nagar, R. 2018. The Possibility of Using the Fresh Water Bivalve, Spathopsis Rubens, in The Nile River, El Mahmoudia Water Stream As Bioindicator For Pollution. International Journal of Limnologi. Vol. 1 No. 1. Pages 1-23.
Rahayu, D. M., Yoga, G. P., Effendi, H., dan Wardiatno, Y. 2015. Penggunaan Makrozoobentos sebagai Indikator Status Perairan Hulu Sungai Cisadane, Bogor. Jurnal Ilmu Pertanian Indonesia. Vol. 20 No.1. Hal. 1-8.

Rahmawati, L. A., dan Setyoningrum, D. 2020. Kualitas Air Sungai di Kawasan Tambang Minyak Tradisional Wonocolo. Bojonegoro. Laporan Hibah Penelitian Dosen Pemula. Universitas Bojonegoro.

Rahmawati, L. A., Afiati, N. and Putranto, T.T. 2021. Impacts of the Covid-19 Pandemic on Traditional Oil Mining at Wonocolo Village Kedewan Sub-District Bojonegoro Regency East Java. IOP Conf. Ser.: Earth Environ.

Sari, G. L., and Trihadiningrum, Y. 2018. Petroleum Hydrocarbon Pollution in Soil and Surface Water by Public Oil Petroleum Hydrocarbon Pollution in Soil and Surface Water by Public Oil Fields in Wonocolo Sub-district, Indonesia. Jurnal of Ecologycal Engineering. Vol. 19 No. 2. Pages 184-193.

Sasongko, E.B., Widyastuti, E., dan Priyono, R.E. 2014. Kajian Kualitas Air Dan Penggunaan Sumur Gali Oleh Masyarakat Di Sekitar Sungai Kaliyasa Kabupaten Cilacap. Jurnal Ilmu Lingkungan Vol. 12 No. 2. Hal. 7282

Setyaningrum, D., Harjono, dan Rizqiyah, Z. 2020. Analisis Kualitas Air Terproduksi Desa Kedewan Kecamatan Wonocolo Kabupaten Bojonegoro. Science Tech: Jurnal Ilmu Pengetahuan Dan Teknologi, Vol. 6286 No. 1. Hal. 1-9.

Siahaan, R., Indrawan, A., Soedharma, D., dan Prasetyo, L. B. 2012. Keanekaragaman Makrozoobentos sebagai Indikator Kualitas Air Sungai Cisadane, Jawa Barat Banten (Macrozoobentos Diversity as Indicator of Water Quality of Cisadane River). Jurnal Bioslogos. Vol. 2 No. 1. Pages 1-9

Sinaga, T. 2009. Keanekaragaman Makrozoo-Bentos Sebagai Indikator Kualitas Perairan Danau Toba Balige Kabupaten Toba Samosir. Tesis Sekolah Pascasarjana Universitas Sumatera Utara.

Sirait, M., Rahmatia, F., Patulloh. 2018. Komparasi Indeks Keanekaragaman dan Indeks Dominansi Fitoplankton di Sungai Ciliwung Jakarta. Jurnal Kelautan. Vol. 11 No. 1. Hal. 75-79

Sujati, A. B., Priyono, A., dan Siti Badriyah, D. 2017. Karakteristik Kualitas Air Sungai Ciliwung di Segmen Kebun Raya Bogor (Water Quality Characteristic of Ciliwung River at Bogor Botanical Garden Segmen, Bogor). Media Konservasi. Vol. 22 No. 2. Pages 111117.

Yogafanny, E., Utami, A., Kristiati, E. A., \& Nandari, W. W. 2019. Rapid Lava Sand Filtration for Decentralized Produced Water Treatment System in Old Oil Well Wonocolo. Jurnal of The Civil Engineering Forum. Vol. 5 No. 2. Pages 113-122. 